\title{
INDUCTION AND INHIBITION OF IMPLANTATION IN LACTATING RATS
}

\author{
RHODA MANECKJEE AND N. R. MOUDGAL \\ Laboratory of Endocrine Biochemistry, Department of Biochemistry, \\ Indian Institute of Science, Bangalore-560012, India
}

(Received 15th Fuly 1974)

\begin{abstract}
Summary. The interrelationship between prolactin and $\mathrm{LH}$ in the maintenance of pregnancy during lactation was studied. The reduction of suckled young from eight to two or less, as late as on the morning of Day 4 of pregnancy, resulted in normal implantation. Reintroduction of eight young on Day 4 to lactating pregnant rats deprived of their litters on Day 1 resulted in an inhibition of implantation, but reintroduction on Days 5 or 6 did not inhibit implantation. If oestrogen, HCG or PMSG was given on Day 4 of pregnancy, implantation was induced at the normal time in rats suckling large litters. When LH antiserum was given on the morning of Day 4 or Day 8 to pregnant rats suckling two young each, it blocked implantation and postimplantation survival of blastocysts, respectively. When the number of suckling young was increased from two to eight on Day 6, however, LH antiserum blocked pregnancy only to the extent of $70 \%$. Prolactin administered during the preimplantation phase inhibited implantation in pregnant rats suckling a minimum number of young, but had no effect when given during the postimplantation phase. Progesterone failed to block implantation. Prolactin had no inhibitory effect on implantation in the absence of the suckling stimulus or in non-lactating pregnant rats. The inhibition of implantation by prolactin in rats suckling two young could be effectively reversed by the administration of oestrogen, PMSG or HCG on Day 4 of pregnancy.
\end{abstract}

\section{INTRODUCTION}

The occurrence of post-partum oestrus in rats may enable the female to become pregnant if she is mated immediately after parturition. Normal implantation which occurs on Day 6 of lactational pregnancy (Day $1=$ day of detection of spermatozoa) is, however, dependent upon the presence of a minimum number (two) of sucking young. Implantation is known to be dependent upon the optimal support of progesterone and oestrogen, and their synthesis requires the proper trophic influence from the pituitary.

It has been suggested that the delayed implantation in lactating pregnant rats suckling a large number of young ( $>$ six) is due to the inhibitory effect of suckling/prolactin on pituitary gonadotrophin release (Rothchild, 1960; 
Brumley \& De Feo, 1964). Rothchild (1960) has postulated that a single neural stimulus, i.e. suckling, brings about a simultaneous inhibition of two hypothalamic factors (prolactin-inhibiting and gonadotrophin-releasing factors), thus resulting in a concomitant increase in prolactin and decrease in folliculotrophin (FSH and LH) levels.

In the present paper, we have attempted to study the nature of the trophic influence required to induce implantation at the normal time in lactating pregnant rats suckling a large number of young and also to dissociate the effects of suckling and prolactin on the inhibition of implantation. An account of a preliminary study has been reported earlier (Maneckjee \& Moudgal, 1973).

\section{MATERIALS AND METHODS}

Animals and experimental procedure

A few days before the expected day of birth, pregnant rats were placed in individual cages, each with a male of proven fertility. On the morning following parturition, the vaginal smears were examined for the presence of spermatozoa (post-partum oestrus occurring within 12 to $24 \mathrm{hr}$ of parturition). If the smear contained spermatozoa, the pregnant rat with its sucking young was separated from the male and housed in another cage. On this day (regarded as Day 1 of lactational pregnancy), the number of sucking young was adjusted to eight, two or none, depending upon the experiment to be conducted. All changes in litter size were carried out at 10.00 hours on the appropriate day. If implantation had taken place normally on Day 6, implantation sites of uniform size could be seen at laparotomy on Day 8. The absence of implantation sites on Day 8 was taken as an indication of delay of implantation. These animals were subjected to a second laparotomy on Day 12 to check for implantation sites.

\section{Hormonal preparations and antisera}

Ovine prolactin (NIH-P-S8), ovine LH (NIH-LH-S16), ovine FSH (Papkoff preparation), HCG and PMSG (Ayerst Laboratories) were dissolved in $0.1 \mathrm{ml}$ of $10 \%$ gelatin (used as a delay vehicle), and administered subcutaneously once daily. Ovine LH was also administered subcutaneously, emulsified in $0.1 \mathrm{ml}$ incomplete Freund's adjuvant or in $0.1 \mathrm{ml}$ of $0.9 \%$ saline by the intracardiac route. Steroid hormones were administered subcutaneously dissolved in $0.1 \mathrm{ml}$ purified peanut oil. The doses of the hormones and duration of treatment are indicated in the Tables. Methods for the preparation and characterization of antiserum to ovine LH have been described earlier by Madhwa Raj \& Moudgal (1970). Specific animals, as indicated in the 'Results' section, received a single injection $(0.2 \mathrm{ml})$ of the well-characterized antiserum by the subcutaneous route at 10.00 hours.

\section{RESULTS}

Effect of change in litter size on implantation in lactating pregnant rats

The control animals suckling eight young each showed a delay in implantation of fertilized ova, implantation sites being observed on Day 12 but not on 
Day 8 of pregnancy. By contrast, those suckling only two young each showed normal implantation sites on Day 8 . The reduction of suckling young from eight to two, one or none, as late as 10.00 hours on Day 4, resulted in implantation by Day 8 (Table 1).

Lactating pregnant rats deprived of their litters on Day 1 of pregnancy had implanted by Day 8 (Table 2, Group I). Reintroduction of litters (eight young) as late as 10.00 hours on Day 4 led to a delay in implantation (Table 2, Group II). When the young were reintroduced at 10.00 hours on either Day 5 or 6 , implantation had occurred by Day 8 (Table 2, Groups III and IV), but the implantation swellings were smaller in size than the normal Day-8 swellings in the Group III rats.

Table 1. Effect of reduction in litter size on Day 4 of implantation in lactating pregnant rats

\begin{tabular}{|c|c|c|c|c|c|}
\hline \multirow{2}{*}{ Group } & \multirow{2}{*}{$\begin{array}{l}\text { No. of young } \\
\text { suckled }\end{array}$} & \multirow{2}{*}{ Treatment } & \multirow{2}{*}{$\begin{array}{l}\text { No. of } \\
\text { rats }\end{array}$} & \multicolumn{2}{|c|}{ No. of implantation sites } \\
\hline & & & & Day 8 & Day 12 \\
\hline I & 8 & Control & 4 & 0 & 28 \\
\hline II & 2 & Control & 4 & 44 & - \\
\hline III & 8 & $\begin{array}{l}\text { No. of young } \\
\text { reduced to two }\end{array}$ & 4 & 46 & - \\
\hline IV & 8 & No. of young & 4 & 31 & 一 \\
\hline $\mathrm{V}$ & 8 & $\begin{array}{l}\text { No. of young } \\
\text { reduced to none }\end{array}$ & 4 & 52 & - \\
\hline
\end{tabular}

Table 2. Effect of reintroducing eight sucking young to lactating pregnant rats deprived of their litters on Day 1 of pregnancy

\begin{tabular}{lccc}
\hline Group & $\begin{array}{c}\text { Day of pregnancy } \\
\text { young reintroduced }\end{array}$ & $\begin{array}{c}\text { No. of } \\
\text { rats }\end{array}$ & $\begin{array}{c}\text { No. of implantation sites } \\
\text { on Day 8 }\end{array}$ \\
\hline I & - (Control) & 4 & 50 \\
II & 4 & 4 & 0 \\
III & 5 & 4 & $34 \dagger$ \\
IV & 6 & 4 & 47 \\
\hline
\end{tabular}

* At 10.00 hours.

$\uparrow$ Implantations in these rats were small.

Induction of implantation in lactating pregnant rats suckling eight young each

Administration of a low dose of oestradiol-17 $\beta$ on the morning of Day 4 to pregnant rats suckling eight young each resulted in implantation by Day 8 (Table 3, Group II), but higher doses were inhibitory (Table 3, Group I). A single dose of 10 i.u. PMSG or 5 i.u. HCG on the morning of Day 4 only, induced implantation at the normal time in pregnant rats suckling eight young each (Table 3, Groups IV and V). Treatment with LH on Day 4 was ineffective in inducing implantation at the normal time (Table 3, Group VI). Similarly, ovine FSH given alone on Day 4 or in combination with LH on Days 3 and 4 was unable to induce implantation (Table 3, Groups VII and VIII). 
Effects of LH antiserum on the course of gestation in lactating pregnant rats

When LH antiserum was administered on the morning of Day 4 (preimplantation) or Day 8 (postimplantation) to pregnant rats suckling two young each, it blocked implantation or resulted in fetal death (Table 4). If, however, LH antiserum was injected at 10.00 hours on Day 8 into rats when the number of their sucking young had been increased from two (Days 1 to 6) to eight on Day 6 , the result was variable. While $30 \%$ were still pregnant on Day 10 after treatment with antiserum on Day 8, complete or partial resorption was observed in the others (Table 4, Group III).

Table 3. Induction of implantation by various hormonal treatments in lactating pregnant rats suckling eight young each

\begin{tabular}{|c|c|c|c|c|}
\hline Group & Treatment & $\begin{array}{c}\text { Day of } \\
\text { treatment }\end{array}$ & $\begin{array}{l}\text { No. of } \\
\text { rats }\end{array}$ & $\begin{array}{l}\text { No. of implantation } \\
\text { sites on Day } 8\end{array}$ \\
\hline $\begin{array}{l}\text { I } \\
\text { II } \\
\text { III } \\
\text { IV } \\
\text { V } \\
\text { VI } \\
\text { VII } \\
\text { VIII }\end{array}$ & 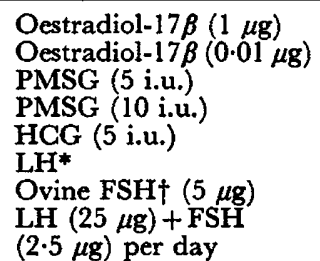 & $\begin{array}{c}4 \\
4 \\
4 \\
4 \\
4 \\
4 \\
4 \\
384\end{array}$ & $\begin{array}{r}4 \\
4 \\
3 \\
5 \\
7 \\
60 \\
4 \\
4\end{array}$ & $\begin{array}{r}0 \\
35 \\
0 \\
22 \\
50 \\
0 \\
0 \\
0\end{array}$ \\
\hline
\end{tabular}

* A wide dose range of $\mathrm{LH}$ ( 1 to $100 \mu \mathrm{g}$ ) was given (see 'Materials and Methods').

$\uparrow$ Equivalent to 45 times NIH-FSH.

Table 4. Effect of LH antiserum on the course of gestation in lactating pregnant rats suckling two young each

\begin{tabular}{|c|c|c|c|c|}
\hline \multirow{2}{*}{ Group } & \multirow{2}{*}{$L H$ antiserum treatment } & \multirow{2}{*}{ No. of rats } & \multicolumn{2}{|c|}{ No. of implantation sites } \\
\hline & & & Day 8 & Day 12 \\
\hline $\begin{array}{l}\text { I } \\
\text { II } \\
\text { III }\end{array}$ & $\begin{array}{l}0.2 \mathrm{ml} \text { (Day 4) } \\
0.2 \mathrm{ml} \text { (Day 8) } \\
\text { Eight young (Day 6) } \\
+0.2 \mathrm{ml}(\text { Day } 8)\end{array}$ & $\begin{array}{r}4 \\
4 \\
10\end{array}$ & $\begin{array}{r}0 \\
42 \\
83\end{array}$ & $\begin{array}{c}\overline{0} \\
29^{*}\end{array}$ \\
\hline
\end{tabular}

* Number in three rats.

Inhibition of implantation by prolactin, and its reversal, in lactating pregnant rats suckling two young each

Lactating pregnant rats suckling two young each were given $100 \mu \mathrm{g}$ prolactin/day in $0.1 \mathrm{ml}$ of $10 \%$ gelatin during the preimplantation period (Days 1 to 7, 1 to 4, Day 4 only, Days 3 and 4, and Days 4 and 5) and post-implantation period (Days 6 and 7). Control rats suckling two young each had implanted by Day 8 (Table 5, Group I), but the animals treated with prolactin during the preimplantation phase had not (Table 5, Groups II, III and IV). An exception to this was the group receiving prolactin on Day 4 only (Table 5, Group V). 
Table 5. Inhibition of implantation by prolactin in lactating pregnant rats suckling two young each

\begin{tabular}{|c|c|c|c|c|}
\hline \multirow{2}{*}{ Group } & \multirow{2}{*}{$\begin{array}{l}\text { Day of pregnancy } \\
\text { prolactin* given }\end{array}$} & \multirow{2}{*}{ No. of rats } & \multicolumn{2}{|c|}{ No. of implantation sites } \\
\hline & & & Day 8 & Day 12 \\
\hline $\begin{array}{l}\text { I } \\
\text { II } \\
\text { III } \\
\text { IV } \\
\text { V } \\
\text { VI } \\
\text { VII } \\
\text { VIII } \\
\text { IX }\end{array}$ & $\begin{array}{l}0 \text { (Control) } \\
1 \text { to } 7 \\
1 \text { to } 4 \\
3 \text { and } 4 \\
4 \\
4 \text { and } 5 \\
5 \text { and } 6 \\
6 \text { and } 7 \\
3 \text { and } 4 \dagger\end{array}$ & $\begin{array}{r}4 \\
4 \\
7 \\
10 \\
8 \\
8 \\
8 \\
8 \\
5\end{array}$ & $\begin{array}{r}44 \\
0 \\
0 \\
0 \\
21 \\
0 \\
30 \\
37 \\
47\end{array}$ & $\begin{array}{l}\frac{}{-} \\
50 \\
\frac{88}{60} \\
\frac{-}{-}\end{array}$ \\
\hline
\end{tabular}

* Prolactin dose $=100 \mu \mathrm{g} /$ day.

$\dagger$ Progesterone $(4 \mathrm{mg})$ was given instead of prolactin on these days.

Table 6. Reversal of prolactin inhibition of implantation by hormone treatment in lactating pregnant rats suckling two young each

\begin{tabular}{|c|c|c|c|c|c|}
\hline \multirow{2}{*}{ Group } & \multirow{2}{*}{ Treatment } & \multirow{2}{*}{$\begin{array}{l}\text { Days of } \\
\text { treatment }\end{array}$} & \multirow{2}{*}{ No. of rats } & \multicolumn{2}{|c|}{ No. of implantation sites } \\
\hline & & & & Day 8 & Day 12 \\
\hline $\begin{array}{l}\text { I } \\
\text { II }\end{array}$ & $\begin{array}{l}\text { Prolactin* } \\
\text { Prolactin }\end{array}$ & $\begin{array}{l}1 \text { to } 4 \\
1 \text { to } 4\end{array}$ & $\begin{array}{l}4 \\
4\end{array}$ & $\begin{array}{r}0 \\
36\end{array}$ & 28 \\
\hline III & $\begin{array}{l}\text { Prolactin } \\
+ \text { PMSG }(10 i . u)\end{array}$ & $\begin{array}{c}1 \text { to } 4 \\
4\end{array}$ & 4 & 39 & - \\
\hline IV & $\begin{array}{l}\text { Prolactin } \\
+\mathrm{LH}(50 \mu \mathrm{g})\end{array}$ & 1 to 4 & 6 & 0 & 37 \\
\hline $\mathrm{V}$ & $\begin{array}{l}\text { Prolactin } \\
\text { +oestradiol-17 } \\
(0.0 \mathrm{l} \mu \mathrm{g})\end{array}$ & $\begin{array}{c}1 \text { to } 4 \\
4\end{array}$ & 4 & 25 & - \\
\hline
\end{tabular}

* Prolactin dose was $100 \mu \mathrm{g} /$ day.

Table 7. Permissive effect of suckling on prolactin action

\begin{tabular}{llccc}
\hline Group & No. of young & $\begin{array}{c}\text { Day of } \\
\text { prolactin } \\
\text { treatment }\end{array}$ & $\begin{array}{c}\text { No. of } \\
\text { rats }\end{array}$ & $\begin{array}{c}\text { No. of implantation } \\
\text { sites on Day 8 }\end{array}$ \\
\hline I & 8 to 2 (Day 4) & - & 4 & 46 \\
II & 8 to 2 (Day 4) & 4 to 7 & 4 & 0 \\
III & 8 to 1 (Day 4) & -7 to 7 & 4 & 31 \\
IV & 8 to 1 (Day 4) & 4 - & 4 & 51 \\
V & 8 to 0 (Day 4) & 4 to 7 & 4 & 46 \\
VI & 8 to 0 (Day 4) & 3 to 7 & 3 & 29 \\
VII & 8 to 0 (Day 4) & 5 to 7 & 5 & $36 \dagger$ \\
VIII & 8 to 0 (Day 5) & 1 to 7 & 7 & 68 \\
IX & Non-lactating & & & \\
& pregnant rats & & & \\
\hline
\end{tabular}

* Prolactin dose was $100 \mu \mathrm{g} / \mathrm{day}$.

† Implantation sites in these rats were small.

$\ddagger$ Prolactin dose was 100 to $300 \mu \mathrm{g} / \mathrm{day}$. 
In all these groups, implantation sites were seen on Day 12. By contrast, when prolactin was given during the postimplantation period, it was unable to inhibit the further development of embryos which had implanted on Day 6 (Table 5, Groups VI, VII and VIII). In order to show that inhibition (or reduction) of gonadotrophin secretion by prolactin takes place directly at the level of the pituitary/hypothalamus and is not mediated through the ovary, an experiment was carried out in which $4 \mathrm{mg}$ progesterone/day was given on Days 3 and 4 to rats suckling two young each. In these rats, there was no blocking of implantation on Day 6 (Table 5, Group IX).

The inhibition of implantation by prolactin can be reversed by treatment with gonadotrophin or oestrogen. Administration of PMSG or HCG on the morning of Day 4 only, together with daily treatment with prolactin from Days 1 to 4, effectively reversed this inhibition (Table 6, Groups II and III). A similar reversal was obtained after treatment with oestradiol-17 $\beta$ on Day 4 only (Table 6, Group V), but LH on Day 4 was unable to overcome the prolactin inhibition of implantation (Table 6, Group IV).

\section{Permissive effect of suckling on prolactin action}

As shown in Table 1, reduction in the number of sucking young from eight to two, one or none on Day 4 of lactational pregnancy resulted in implantation at the normal time. When the number of their young was reduced from eight to two or one on the morning of Day 4, prolactin given from Days 4 to 7 resulted in an inhibition of implantation (Table 7, Groups II and IV). By contrast, if the number of young was reduced to none on Days 4 or 5 and prolactin was administered on Days 3 to 7, 4 to 7, or 5 to 7 (Table 7, Groups VI, VII and VIII), no inhibition of implantation was observed. Similarly, prolactin injection on Days 1 to 7 to non-lactating pregnant rats had no inhibitory effect on implantation (Table 7, Group IX).

\section{DISCUSSION}

The inhibition of lactation on implantation appears to be an easily reversible process in rats. Withdrawal of or reduction in the suckling stimulus, even by 10.00 hours on Day 4 of lactational pregnancy, induces implantation at the normal time on Day 6, suggesting that the removal of the inhibitory effect of lactation on LH release is almost immediate and also that the ovary is in a ready state to respond to the correct level of $\mathrm{LH}$ to produce the required oestrogen. The observation that the LH level increases significantly within $8 \mathrm{hr}$ of withdrawal of or reduction in the suckling stimulus supports the first of these suggestions (K. Muralidhar, R. Maneckjee and N. R. Moudgal, unpublished data).

The observation that $\mathrm{LH}$ antiserum also inhibits implantation in lactating pregnant animals shows that the hormonal requirement for implantation is the same as in normal pregnancy. That the implantation block observed in lactating pregnant rats suckling large litters is not due to the lack of gonadal responsiveness to gonadotrophins, but may be due to an actual reduction in gonadotrophin availability, is evident from the gonadotrophin supplementation 
experiments. Rothchild (1960), using the ovarian response of the lactating rat to exogenous FSH plus $\mathrm{LH}$, also came to a similar conclusion. The ineffectiveness of ovine LH, as compared to PMSG and HCG, in reversing the implantation block in rats suckling large litters may be due to the relatively shorter tissue half-life and specific activity of ovine LH. Whitten (1955, 1958) using lactating mice and Weichert (1940) using lactating rats observed that the gonadotrophic factor in pregnancy urine or HCG and PMSG were capable of inducing implantation. More work needs to be done on the nature of the vehicle and the dosage before the amount of LH necessary to bring about implantation can be determined.

The essential difference between the rats subjected to intense and to mild suckling was that, in addition to the degree of suckling stimulus, there was a significant increase in the level of prolactin in the former group (Ford \& Melampy, 1973). The results of the present experiments demonstrate clearly that the true causative agent for effective block of $\mathrm{LH}$ secretion is prolactin, and not the intensity of suckling. The suckling stimulus is, however, essential and plays an important rôle by way of 'permitting' prolactin to cause an inhibition of implantation. The permissive effect was clearly demonstrated in the experiment in which prolactin was able to cause inhibition of implantation even if the lactating pregnant mother was suckling only one young. This is supported by the fact that prolactin was unable to affect implantation when administered to non-lactating pregnant rats. The mechanism of this permissive effect is, however, unclear.

Lactating pregnant rats suckling only two young each appear to be similar to non-lactating pregnant rats in being sensitive to $\mathrm{LH}$ antiserum during the preand postimplantation phases. Prolactin, in contrast to $\mathrm{LH}$ antiserum, is only able to block implantation. The difference between the action of prolactin and LH antibody appears to be that while the latter neutralizes all available LH, the inhibitory effect of prolactin on $\mathrm{LH}$ release is probably not complete. The reduction in LH secretion may be sufficient to inhibit the oestrogen synthesis needed for implantation, but perhaps is not enough to block the ovarian progesterone output needed for postimplantation survival of blastocysts, and suggests the existence of a differential threshold of LH during the pre- and postimplantation periods (Maneckjee, 1973).

\section{ACKNOWLEDGMENTS}

The authors wish to thank the Indian Council of Medical Research, New Delhi, the Ford Foundation, New York, and the Council of Scientific and Industrial Research, New Delhi, of which R.M. was a Senior Research Fellow, for financial assistance, and Mr P. Pasupathy for typing this manuscript.

\section{REFERENCES}

BRUMLEY, L. E. \& DE Feo, V. J. (1964) Quantitative studies on deciduoma formation and implantation in the lactating rat. Endocrinology, 75, 883-892.

FoRd, J. J. \& MELAMPY, R. M. (1973) Gonadotrophin levels in lactating rats. Endocrinology, 93, 540-547.

Madhwa Raj, H. G. \& Moudgal, N. R. (1970) Hormonal control of gestation in the intact rat. Endocrinology, 86, 874-889. 
Maneckjee, R. (1973) Studies on pseudopregnancy and pregnancy in normal and lactating rats. Ph.D. thesis, Indian Institute of Science, Bangalore, India.

Maneckjee, R. \& Moudgal, N. R. (1973) Inhibition of implantation in lactating rats. International Research Communication System (73-5), 15-14-5.

RoтнсніLd, I. (1960) The corpus luteum-pituitary relationship: the association between the cause of luteotrophin secretion and the cause of follicular quiescence during lactation; the basis for a tentative theory of the corpus luteum-pituitary relationship in the rat. Endocrinology, 67, 6-41.

Weichert, C. K. (1940) The experimental shortening of delayed pregnancy in the albino rat. Anat. Rec. $77,31-47$.

Whitten, W. K. (1955) Endocrine studies on delayed implantation in lactating mice. F. Endocr. $13,1-6$.

Whitten, W. K. (1958) Endocrine studies on delayed implantation in lactating mice. Role of the pituitary in implantation. 7. Endocr. 16, 435-440. 